Biografistyka Pedagogiczna

Rok 2 (2017) nr 1

ISSN 2543-6112; e-ISSN 2543-7399

DOI: $10.36578 /$ BP.2017.02.11

Oleh Rudenko*

\title{
Ciężki los łagodnego naukowca Piotra Bohdana Krypiakiewicza
}

\section{The Hard Life of Gentle Scientist Piotr Bohdan Krypiakiewicz}

\begin{abstract}
This article is dedicated to Piotr Bohdan Krypiakiewicz (1923-1980), who was one of the founders of the school of crystal chemistry at the University of Lviv) and the son of an outstanding Ukrainian historian. Throughout his scientific life he struggled with the effects of the then incurable disease (poliomyelitis) from which he suffered during his studies. Although he was seriously ill, he graduated from university, defended his doctorate and made a habilitation. He worked at the university, where he conducted a diploma seminar, and held meetings with students at home. He cared about the level of education, supported the young, read, edited monographs and papers on crystal chemistry and crystallography and published research results in journals. Moreover, he was very noble, cheerful and never showed anyone how much he was suffering.
\end{abstract}

Keywords: Piotr Bohdan Krypiakiewicz, crystal chemistry, professor of the Lviv University, disability

* Oleh Rudenko - dr, docent w Katedrze grafiki książkowej i warsztatowej Ukraińskiej Akademii Drukarstwa we Lwowie, rudenko@wp.pl. 
Piotr Bohdan Krypiakiewicz urodził się 10 lutego 1923 r. we Lwowie w rodzinie o korzeniach szlacheckich, był synem słynnego ukraińskiego historyka, akademika i profesora Iwana Krypiakiewicza i Marii z domu Sydorowiczów. Pierwsze imię dostał na pamiątkę po dziadku Piotrze Francu Krypiakiewiczu, jednym z pierwszych Ukraińców, który zdobył stopień doktora teologii w Wiedniu, drugie nawiązywało do ulubionego bohatera, którym zajmował się ojciec w badaniach historycznych - Bohdana Chmielnickiego. Członkowie rodziny, ukraińscy inteligenci w czasach totalitaryzmu byli prześladowani, ale nie ulegli pokusie łatwiejszego życia w rzeczywistości sowieckiej. Piotr Bohdan był człowiekiem wierzącym i żył zgodnie z zasadami światopoglądu chrześcijańskiego - cierpiał, ale nie zdradził swoich przekonań. Ojciec, wiedząc, czym jest „szczęśliwe” życie człowieka radzieckiego, podczas drugiej wojny światowej chciał wyjechać z rodziną za granicę. Nie zdążył tego uczynić, jedynie synowie wyjechali do Wiednia, gdzie oczekiwali na dalszą decyzję ojcaํ. Iwan Krypiakiewicz, historyk-konserwatysta pozostał na radzieckiej Ukrainie i przez całe życie, jak tylko mógł, przeciwstawiał się reżimowi, a dwaj synowie zajmowali się nauką. Piotr Bohdan i jego młodszy brat Roman obronili prace doktorskie, natomiast habilitacje zdążył obronić tylko starszy, młodszy przed obroną został zwolniony z pracy, ponieważ należał do niepodległościowego ruchu ukraińskiego w latach sześćdziesiątych XX w. - tak zwanych „sześciodziesiątników”2. Wyniesione z domu rodzinnego wartości towarzyszyły braciom przez całe życie, a także dodawały sił, aby nie poddać się, nie dać się zwieść „dobrodziejstwom” sowieckiej rzeczywistości i nie wstąpić na drogę konformizmu. Gdy nieoczeki-

1 Wszystkie rzeczy były już spakowane i odesłane do Krynicy, ale żona przebywała w letnim domku w Kuderiawcach pod Tarnopolem, należącym do rodziny, do którego wkroczyły już wojska radzieckie. Iwan Krypiakiewicz postanowił nie uciekać, a pozostać z żoną. Synowie Piotr Bohdan i Roman przebywali w Wiedniu, między 1943 a 1944 r. jako żołnierze zostali wcieleni do wojska. Bardzo szybko ich zdemobilizowano z powodu studiów na Uniwersytecie Wiedeńskim. Piotr Bohdan i Roman po jakimś czasie wrócili do Lwowa. Właśnie ta przygoda synów była wypominana Iwanowi Krypiakiewiczowi, którego z tego powodu szantażowała Służba Bezpieczeństwa Związku Radzieckiego.

2 Ruch w obronie praw człowieka i odrodzenia kultury rodzimej w latach sześćdziesiątych xX w. na Ukrainie, nazwany „sześciodziesiątnikami”. Wśród członków byli między innymi działacze kultury Iwan Dracz, Wasyl Symonenko, Serhij Paradżanow, Ałła Horska, Iwan Dziuba. 
wanie starszy brat zachorował, młodszy zaopiekował się nim, towarzyszył mu w trudnych chwilach i wspierał go do końca życia.

Piotr Krypiakiewicz zaczynał edukację w okresie Drugiej Rzeczypospolitej. W 1934 r. we Lwowie uczęszczał do państwowego gimnazjum, które znajdowało się w pałacu hrabiego Siemieńskiego przy ul. Piekarskiej 19. Do gimnazjum tego chodził także młodszy brat Roman, a w latach 1921-1925 pracował ich ojciec. Budynek nie był przystosowany do zajęć szkolnych, a gabinet dyrektora, pana Michała Zaleskiego, „nie pasował do wielkiej osoby, która w nim rezydowała”. Pełne uroku kilkustronicowe wspomnienia Piotra Bohdana ukazują czasy przed drugą wojną światową. W szkole znajdowała się kaplica, ale gdy na dworze było ciepło, na poranną liturgie chodziło się do cerkwi grekokatolickiej Preobrażeńskiej (Przemienienia Pańskiego), która znajdowała się na ul. Krakowskiej. Jako gimnazista Piotr z przyjaciółmi chodził na przedstawienia do Teatru Wielkiego we Lwowie. Obejrzał m.in. sztuki dramatyczne Aleksandra Fredry, Juliusza Słowackiego, Stanisława Wyspiańskiego, Wiliama Szekspira, Moliera, Maurice'a Maeterlincka, Friedricha Schillera. Zapoznawał się także z dziełami Franza Schuberta i innych mistrzów muzyki na lekcjach-koncertach, które odbywały się w wielkiej sali konserwatorium, ozdobionej w stylu zakopiańskim. W szkole pracowało kilku doktorów, wśród nich znaleźli się jego ulubieni nauczyciele: fizyk Zenon Chrapliwy i matematyk Zenon Zielony. Lekcje prowadzono w języku polskim, ale niektóre także po ukraińsku. Historyk ruchu sportowego we Lwowie, miłośnik sztuki i folkloru, Stefan Hajduczok prowadził przedmiot „ćwiczenia dla ciała”, ale także opowiadał o etnologii, topografii i własnym życiu, dbał zawsze o język ukraiński.

Po rozpoczęciu drugiej wojny światowej Piotr Bohdan w 1940 r. otrzymał dyplom z wyróżnieniem państwowego gimnazjum i dostał się na studia, wybrał chemię na Wydziale Przyrodniczym Uniwersytetu Lwowskiego. Wojna i reorganizacja uniwersytetu sprawiły, że musiał się przenieść na Politechnikę Lwowską (Technische Fachkurse), na której studiował w latach 1942-1944, a następnie na Wydział Chemiczny Politechniki Wiedeńskiej (1944-1945). Po zakończeniu wojny, w 1945 r., bracia Piotr Bohdan i Roman głodni i niewyspani, w ubraniach, z których zostały tylko strzępy, na piechotę, jako jeńcy, wrócili z Wiednia

3 П. Крипякевич, Фрагменти спогадів (1934-1939), w: Іван Крип'якевич у родинній традиціï, науці, суспільстві, red. Я. Ісаєвич, Ф. Стеблій, Львів 2001, s. 684. 
do Lwowa. Rodzice płakali, gdy zobaczyli młodzieńców zmęczonych i wycieńczonych drogą. Po wojnie we Lwowie żyło się ciężko, a władza totalitarna nie dawała spokoju - ojciec, ze względu na to, że był znanym historykiem, został odesłany ze Lwowa do Kijowa, pracował w bibliotece, a przedstawiciele władzy myśleli, co z nim dalej uczynić. Piotr Bohdan chciał w roku akademickim 1945/1946 wrócić na Uniwersytet Lwowski na studia, na chemię. Niestety, w czasie wakacji wyjechał z bratem na kąpielisko w Bruchowiczach, gdzie zaraził się wirusem polio i zachorował na chorobę Heinego-Medina (poliomyelitis). Siostra stryjeczna, córka Lwa Krypiakiewicza, Lukija Łukomska (w gronie rodzinnym nazywana „Łucia”) wspomina te czasy, kiedy przyjechała ze Stanisławowa studiować architekturę na Politechnice Lwowskiej i wynajmowała mieszkanie niedaleko Krypiakiewiczów ${ }^{4}$. Często przychodziła do stryja Iwana na obiady. Pewnego razu, gdy przekroczyła próg domu, powiedziano jej, żeby rozmawiała cicho, gdyż jej brat zachorował. Piotr miał sparaliżowane kończyny: ręce i nogi. Zaaplikowano mu kurację penicyliną, w rękach częściowo odzyskał sprawność, ale już nigdy nie mógł chodzić. W latach 1946-1949 cała rodzina koncentrowała się na ciężkiej chorobie „Dania” - tak zdrobniale (od drugiego imienia) nazywano go w rodzinie miała nadzieję, że da się go wyleczyć. Piotr Bohdan wyjeżdżał do sanatorium, przechodził różne kuracje $\mathrm{e}^{5}$. Choroba jednak już nigdy nie pozwoliła mu samodzielnie wstać z krzesła. Jak wspominał jego przyjaciel, znany ukraiński historyk, profesor Jarosław Daszkiewicz, „leżał on w domu w niedużym ciemnym pokoju od strony podwórka, pewien czas - na skrzyżowaniu między życiem a śmiercią... ..." Choroba przekreśliła nadzieje, na jakieś życie osobiste. Nie zważając na trudności, w 1951 r. Piotr Bohdan jako eksternista ukończył z wyróżnieniem Wydział

4 Lukija Krypiakiewicz (po mężu Łukomska) zasłużony architekt Ukrainy - córka brata Iwana Krypiakiewicza, Lwa, językoznawcy, który pod czas drugiej wojny światowej wyjechał do Stanów Zjednoczonych, gdzie zmarł 1974 r., nie zobaczywszy córki.

5 We Lwowie przed wojną istniała tradycja, aby do członków rodziny zwracać się zdrobniale, pieszczotliwie. Do brata Romana mówiono „Romo”. Znamy to także z lwowskich kabaretów międzywojennym, w których posługiwano się zdrobnieniami nawet w pseudonimach artystycznych, np. Szczepko i Tońko. W tradycji rodzinnej nasz bohater miał na pierwsze imię Piotr, a drugie Bohdan (imiona po chrzcie), ale w pracy zwracano się do niego w składni rosyjskiej Piotr Iwanowicz, tak jak było to zapisano w dowodzie osobistym.

6 Я. Дашкевич, Петро Богдан Крип'якевич. Канва спогадів, w: Іван Крип'якевич у родинній традиції, науці, суспільстві, red. Я. Ісаєвич, Ф. Стеблій, Львів 2001, s. 697. 
Chemii Uniwersytetu Lwowskiego. Błyskotliwy umysł absolwenta zauważył kierownik katedry chemii nieorganicznej ${ }^{7}$ Eugeniusz Czerkaszyn ${ }^{8}$, który postanowił dać szansę młodemu człowiekowi i sprawił, że mógł on kontynuować naukę i pozostać do końca życia w środowisku uniwersyteckim.

W 1949 r. Piotr Bohdan razem z kierownikiem katedry opublikował pracę teoretyczną o klasyfikacji faz pośrednich związków chemicznych, a w następnym roku - eksperymentalne badania struktury krystalochemicznego związku CuMgSn 9 . Czerkaszyn, popierany przez akademików M. Biełowa, H. Bokija, I. Francewicza, wystosował do ministerstwa oświaty i Rosyjskiej Akademii Nauk petycję, w której zabiegał o to, aby Piotr Bohdan Krypiakiewicz mógł prowadzić pracę naukową i propedeutyczną - seminaria, konsultacje, promować powstawanie prac magisterskich - w miejscu zamieszkania ${ }^{10} . \mathrm{Z}$ biegiem czasu Piotr Bohdan pod kierunkiem Czerkaszyna obronił w 1957 r. pracę doktorską, a 1972 r. zrobił habilitację na podstawie rozprawy Strukturalne rodzaje intermetalicznych związków, która później ukazała się drukiem ${ }^{11}$. Krypiakiewicz był autorem 236 publikacji naukowych, których opisy bibliograficzne, zebrane przez współpracowników, wydrukowano w zestawieniu bibliograficznym wydanym po śmierci autora ${ }^{12}$. Większość artykułów to prace nad badaniami

7 W latach sześćdziesiątych katedra chemii nieorganicznej uniwersytetu szybko rozwijała się i przyjmuje się, że jej pracownicy tworzyli „lwowską szkołę krystalochemiczną". Є. Гладишевський, Петро Богдан Іванович Крип'якевич - видатний український кристалохімік, w: Іван Крип'якевич у родинній традиції, науці, суспільстві, red. Я. Ісаєвич, Ф. Стеблій, Львів 2001, s. 692.

8 Eugeniusz Czerkaszyn, wybitny uczony, po wojnie przybył z Charkowa i w latach 1945-1968 kierował katedrą chemii nieorganicznej Uniwersytetu Lwowskiego. Pochodził z wołyńskiej rodziny kapłańskiej, w stosunku do współpracowników był wyrozumiały, taktowny. Starał się życie uniwersytecie koncentrować wyłącznie na problemach naukowych, przygotował wielu uczniów i stał się współzałożycielem lwowskiej szkoły krystalochemicznej; tamże.

9 П. Крип'якевич, Е. Гладишевский, Е. Черкашин, Кристаллическая структура тройной фазы CuMgSn, „Доклады Ан ссср” (Москва), 75 (1950) nr 2, s. 205-207.

10 Є. Гладишевський, Петро Богдан Іванович Крип'якевич - видатний український кристалохімік, s. 692.

11 П. Крипякевич, Структурные типь интерметаллических соединений, Москва $1977,288 \mathrm{~s}$.

12 Петро-Богдан Іванович Крип'якевич (1923-1980). Бібліографічний довідник, red. О. Бодак, Є. Гладишевський, Львів 2003, s. 48-67, 71-75. 
różnorodnych struktur i typów kryształów, na końcu pracy wymieniono na czterech stronach formuły odkrytych przez niego związków intermetalicznych. On był, jak zauważyła jego studentka, Hałyna Kyrcziw: „generatorem idei w katedrze chemii nieorganicznej"13.

Ponieważ Piotr Bohdan Krypiakiewicz nie mógł samodzielnie poruszać się i daleko wyjeżdżać, dlatego „oddział” katedry chemii nieorganicznej Uniwersytetu Lwowskiego „tymczasowo znajdował się w jego mieszkaniu”. W niewielkim pokoju, siedząc na łóżku, przyjmował studentów, prowadził seminaria doktoranckie. Jemu nie potrzebna była pracownia - do większości własnych wynalazków dochodził na podstawie rozważań teoretycznych. Posiadał nieprzeciętną wiedzę w zakresie właściwości materiałów, opisywał więc domniemane badania i stawiał hipotezy, które uczniowie sprawdzali w praktyce. Prawie wszystkie przypuszczenia sprawdzały się w badaniach. Żona brata wspomina, jak często zapraszał ją do pokoju, żeby pokazać i wytłumaczyć strukturę i wzajemne połączenie tego lub innego sklejonego z kartonu kryształu ${ }^{14}$. Wiele lat po śmierci Piotra Bohdana widziałem dziesiątki modeli białych kryształów, umieszczone w piwnicy budynku, w którym wszyscy mieszkali, znajdująca się tam szafa, niczym białym śniegiem, „zasypana” była wyklejanymi przez niego modelami.

Aby Piotr Bohdan mógł wygodnie pracować, obok łóżka na odległości wyciągniętej ręki stał stół, na którym wszystko było wzorowo poukładane. Każda rzecz do czegoś służyła, miała swoje określone miejsce i leżała tak, żeby chory mógł ją dostać bez pomocy innej osoby. W mieszkaniu nie miał jakichś osobliwych technicznych środków do badań chemicznych. Zazwyczaj głównymi „pomocnikami” w pracy był suwak logarytmiczny i urządzenia do rysunku takie jak np. ołówek, cyrkiel. Jeżeli ktoś obcy wchodził do pokoju profesora, to on lewą ręką podtrzymywał prawą, chorą rękę, żeby podać ją do przywitania. Radośnie konwersował z rozmówcą o różnych rzeczach. Posiadał łagodny, szczery, pogodny charakter. Nie tolerował niepotrzebnych, próżnych rozmów i nigdy nie podnosił głosu na studenta. Gdy z kimś nie zgadzał się, nie krzyczał, nie kłócił się, wolał milczeć.

Atmosfera w domu Krypiakiewiczów była bardzo życzliwa. Ojciec i matka robili wszystko, aby syn rozwijał się, a drzwi ich domu zawsze były otwarte dla

13 Г. Кирчів, Петро Іванович, w: Іван Крип'якевич у родинній традиції, науці, суспільстві, red. Я. Ісаєвич, Ф. Стеблій, Львів 2001, s. 699.

14 Л. Крип'якевич, Любов перекривала всі труднощі, „Кана”, 2 (2016) nr 2, s. 25. 
studentów. Często wybitny historyk sam wpuszczał gości i w korytarzu prowadził rozmowę z uczniami syna na różne tematy. Młodzi wiedzieli, że rozmawiają z legendarnym człowiekiem - twórcą pierwszej małej, przekrojowej historii Ukrainy, którą czytali, gdy byli dziećmi, i która w tym czasie była zakazana przez władze radzieckie. Hałyna Kyrcziw, która twierdzi, że ludzi przewlekle chorzy mają ciężki, niezrównoważony charakter, była zdziwiona tym, że Piotr Bohdan nie miał tych cech, a wręcz przeciwnie: sprawiał wrażenie spokojnej i życzliwej osoby. Rozmowę prowadził powoli, nie podwyższając głosu - robił wszystko, aby studentka nie odczuwała, jak bardzo jest niedoświadczonym naukowcem, ale brała czynny udział w rozmowie ${ }^{15}$. Zalecał lekturę słowników, aby prace naukowe były pisane dobrym, starannym, wykwintnym językiem, mówił, że: „Każde słowo - to jest skarb i nie wolno nim rozrzucać się" ${ }^{\text {.16. Nie }}$ raz zwracał studentom napisane przez nich prace, aby dopracowali je niemalże do perfekcji.

Jarosław Daszkiewicz wskazuje, że Piotr Bohdan już jako gimnazista „zawsze był bardzo skoncentrowany, poważny" ${ }^{17}$. Po drodze z gimnazjum do domu prowadził rozmowy na tematy naukowe. Miłość do rozważań teoretycznych towarzyszyła mu przez całe życie, a pęd do wiedzy poszerzał krąg jego zainteresowań. Interesował się życiem innych narodów, kulturą - jeżdżąc na kurację do Gruzji, nauczył się języka gruzińskiego. Miał starą maszynę do pisania - opanował alfabet Brajla i pisał listy do nieznajomego niewidomego. Lubił kolekcjonować znaczki pocztowe, oglądać i układać filatelistyczne albumy. Pani Łukija Łukomska przypomina, że Piotr Bohdan był wielbicielem lwowskiej kolei tramwajowej - kreślił mapy, na których zaznaczał rozbudowę nowych linii tramwajowych, a także zbierał bilety. Na początku lat siedemdziesiątych wysłał do syna Łukomskiej narysowany przez siebie odręczny plan kolei miejskiej oraz różnego rodzaju bilety, z czego syn bardzo się cieszył.

Piotr Bohdan znał języki i lubił czytać Honoré de Balzaca i Johna Galsworthy'ego. Miał nieprzeciętną wiedzę na temat dziejów ludzkości, której mógł mu pozazdrościć nawet wykształcony historyk. Pamiętał daty i wydarzenia, bitwy,

15 Г. Кирчів, Петро Іванович, s. 699.

16 О. Залуцька, Людина-легенда, w: Іван Крип'якевич у родинній традиціі, науці, суспільстві, red. Я. Ісаєвич, Ф. Стеблій, Львів 2001, s. 701.

17 Я. Дашкевич, Петро Богдан Крип'якевич. Канва спогадів, s. 696. 
zwycięstwa i porażki. Kochał muzykę, zwłaszcza symfonie Gustava Mahlera i kwartety Antona Brucknera. Miał dużo płyt z nagraniami muzyki klasycznej, których słuchał, z entuzjazmem komentując wykonanie utworów Johanna Sebastiana Bacha, Georga Friedricha Händla, Wolfganga Amadeusza Mozarta, Wilhelma Richarda Wagnera. Ulubioną operą Krypiakiewicza był utwór Śpiewacy norymberscy [Die Meistersinger von Nürnberg] Wagnera. Jego uczeń przypomina, że często dyskutował z nim nie tylko o muzyce, ale także o sztuce, technikach artystycznych, w których jego wiedza nie była dyletancką ${ }^{18}$. Sam grał na skrzypcach, lubił rozmawiać o różnych rodzajach instrumentów, ich brzmieniu, cenił zwłaszcza altówkę. Kiedy ktoś wyjeżdżał do stolicy, prosił, aby mu kupił jakąś płytę. Student Dmytro Frankiewicz wspomina, że na zamówienie kupił w Moskwie płytę z nagraniem symfonii Louisa Hectora Berlioza Harold en Italie. Ten dramat muzyczny po latach przypominał Frankiewiczowi o nauczycielu, o ciężkim losie rodziny Krypiakiewiczów, która cierpiała, zwłaszcza z powodu prześladowań władz radzieckich ${ }^{19}$. Piotr Bohdan lubił nie tylko muzykę, ale znał się także na różnych sztukach plastycznych. Bardzo lubił oglądać i opowiadać o płótnach angielskich malarzy, zwłaszcza Thomasa Gainsborough i Johna Constable'a. Był obeznany ze sztuką awangardy, dziełami Kazimierza Malewicza, Wasyla Kandyńskiego. Rozmowa z Piotrem Bohdanem była zawsze interesująca i zachwycająca, stanowiła „ucztę dla ducha” - dawała dużo pozytywnych emocji, poszerzała horyzonty, zachęcała do pracy nad sobą ${ }^{20}$.

Jeżeli mówić o cechach osobistych Piotra Bohdana i jego wychowaniu, to od dziecka miał naturę delikatną i był bardzo wrażliwy na innych ludzi, starał wesprzeć i pomóc, w czym tylko mógł. Aleksandra Cegielska, bratowa, która spędziła z nim nie jeden dzień, mieszkając z chorym w tym samym mieszkaniu, przypomina, że pewnego razu, gdy nikogo nie było w domu, spadł z łóżka i nie mógł się podnieść na chorych, niewładnych nogach. Słysząc kroki w korytarzu i wiedząc, że ona przyszła, żeby nie przerazić jej, zawołał: „Nie bój się, nie

18 О. Зареченюк, Спогади, w: Петро-Богдан Іванович Крип'якевич (1923-1980). Бібліографічний довідник, red. О. Бодак, Є. Гладишевський, Львів 2003, s. 41.

19 Д. Франкевич, Мій керівник дипломної та дисертаційної робіт, w: ПетроБогдан Іванович Крип'якевич (1923-1980). Бібліографічний довідник, red.

О. Бодак, Є. Гладишевський, Львів 2003, s. 47.

20 О. Зареченюк, Спогадu, s. 41. 
bój się, ja tylko tutaj na podłodze odpoczywam"21. Często wyjeżdżał z młodszym bratem na ulubione wycieczki po Lwowie. Samochodem zwiedzali miejsca zabytkowe, opisane przez ich ojca Iwana Krypiakiewicza w Historycznych wycieczkach po Lwowie ${ }^{22}$. Brat zawsze opiekował się nim, wykazując prawdziwą braterską miłość i powagę. Roman jako młodszy zasięgał rady „Dania” i jego opinia była ważna w jego naukowych rozważaniach nad właściwościami metali czy życiowych wydarzeniach, gospodarstwie domowym. Co jakiś czas przywoził Piotra Bohdana na obronę prac naukowych i „prawie wnosił na rękach” do sali egzaminacyjnej ${ }^{23}$. Dzielnie czekał na brata, dopóki prelegenci nie obronią pracy.

Godne uwagi i powagi życie Piotra Bohdana Krypiakiewicza było przepełnione fizycznym bólem, ale znalazł on w sobie tytaniczną siłę, aby zajmować się nauką, badając i odkrywając nowe związki kryształów, stając się jednym z twórców lwowskiej szkoły krystalochemicznej. Razem z innymi naukowcami katedry chemii nieorganicznej Uniwersytetu Lwowskiego odkrył ponad 550 intermetalicznych związków i ustalił ich krystaliczną budowę ${ }^{24}$. Jego nazwisko znalazło się w Historical Atlas of Crystallography ${ }^{25}$. Miał łagodny charakter, dlatego nawet najbliższym nie okazywał udręki ani goryczy z powodu niedomagania. Będąc człowiekiem głęboko religijnym, cierpiąc, przyjął postawę Hioba, odrzucił pokusę czynnego uczestnictwa w życiu politycznym kraju, nie chciał zostać działaczem partyjnym i objąć wysokiego stanowiska, nawet profesora - ze stopniem doktora habilitowanego pracował na stanowisku „starszego naukowego współpracownika" katedry krystalochemicznej i miał pół etatu.

Jak wspomina jego studentka, Orysia Załucka, w relacjach międzyludzkich był miły i łagodny, nie lubił wszelkiego patosu, natomiast jeżeli chodziło o sprawy naukowe, był bardzo wymagający: „Byłam pod wrażeniem męstwa i siły woli tego chudego i chorego człowieka. Niezwykle delikatny, czuły, bezinteresowny, ludzki, zwracający uwagę na uczniów, jednak wymagający, i pryncypialny, jeżeli

21 Л. Крип'якевич, Любов перекривала всі труднощі, s. 26.

22 I. Крип'якевич, Історичні проходи по Львові, Львів 1991, $167 \mathrm{~s}$.

23 Г. Кирчів, Петро Іванович, s. 700.

24 P. Villars, Pearson's Handbook of Crystallographic Data for Intermetallic Phases, t. 1-2, Ohio 1997 , s. 2886.

25 J. Lima-de-Faria, Historical Atlas of Crystallography, Dordrecht-Boston-London 1990, s. 1980. 
chodziło o badania naukowe"26. Także Daria Semenyszyn dostrzegała w jego charakterze „poświęcenie, poczucie obowiązku, odpowiedzialność, rzetelność i uczciwość naukowa, ciekawość ludzi i wielką dobroć" ${ }^{27}$. Własnej nieuleczalnej chorobie przeciwstawił męską siłę, ciepłe serce i łagodny charakter naukowca. Nigdy go nikt nie widział zdenerwowanego, niezadowolonego z życia, zawsze miał pozytywne usposobienie. Dla Piotra Bohdana Krypiakiewicza, oprócz osiągnięć intelektualnych osoby, ważne były nie odznaczenia, regalia społeczne, ale przede wszystkim wartości etyczne, które decydowały o sposobie zachowania człowieka wobec innych. Nieuleczalna choroba poraziła jego ciało, ale nigdy nie owładnęła duchem i poczuciem godności, które zachował przez całe swoje naukowe życie.

Streszczenie: Artykuł poświęcony jest jednemu z fundatorów szkoły krystalochemicznej na Uniwersytecie Lwowskim Bohdanowi Piotrowi Krypiakiewiczowi (1923-1980), synowi wybitnego ukraińskiego historyka. Przez całe swoje życie naukowe walczył ze skutkami nieuleczalnej w tym czasie choroby (poliomyelitis), na którą zapadł podczas studiów. Mimo iż był ciężko chory, nie tylko skończył uniwersytet, ale obronił doktorat, następnie zrobił habilitację. Pracował na uniwersytecie, prowadząc seminarium dyplomowe i spotkania ze studentami w domu. Dbał o poziom wykształcenia, wspierał młodych, czytał, redagował monografie, referaty z krystalochemii i krystalografii, publikował wyniki badań w czasopismach. Oprócz tego był bardzo szlachetny, posiadał pogodę ducha i nigdy nie wykazywał innym, jak bardzo cierpi.

Słowa kluczowe: Bohdan Piotr Krypiakiewicz, krystalochemia, profesor Uniwersytetu Lwowskiego, niepełnosprawność

\section{Bibliografia}

Lima-de-Faria J., Historical Atlas of Crystallography, Dordrecht-Boston-London 1990. Villars P., Pearson's Handbook of Crystallographic Data for Intermetallic Phases, Ohio 1997. Гладишевський Є., Петро Богдан Іванович Крип'якевич - видатний український кристалохімік, w: Іван Крип'якевич у родинній традиціi, науиі, суспільстві, red. Я. Ісаєвич, Ф. Стеблій, Львів 2001.

26 О. Залуцька, Людина-легенда, s. 701.

27 Д. Семенишин, Пам'яті П.І. Крип'якевича, ш: Петро-Богдан Іванович Крип'якевич (1923-1980). Бібліограббічний довідник, red. О. Бодак, Є. Гладишевський, Львів 2003, s. 42. 
Дашкевич Я., Петро Богдан Крип'якевич. Канва спогадів, w: Іван Крип'якевич у родинній традиціï, науці, суспільстві, red. Я. Ісаєвич, Ф. Стеблій, Львів 2001.

Залуцька О., Людина-легенда, w: Іван Крип'якевич у родинній традиції, науці, суспільстві, red. Я. Ісаєвич, Ф. Стеблій, Львів 2001.

Зареченюк О., Спогади, w: Петро-Богдан Іванович Крип'якевич (1923-1980). Бібліографбічний довідник, red. О. Бодак, Є. Гладишевський, Львів 2003.

Кирчів Г., Петро Іванович, w: Іван Крип'якевич у родинній традиції, науці, суспільстві, red. Я. Ісаєвич, Ф. Стеблій, Львів 2001.

Крип'якевич І., Історичні проходи по Львові, Львів 1991.

Крип'якевич Л., Любов перекривала всі труднощі, „Кана”, 2 (2016) nr 2.

Крип'якевич П., Е. Гладишевский, Е. Черкашин, Кристаллическая структура тройной фазы CuMgSn, „Доклады Ан ссср” (Москва), 75 (1950) nr 2.

Крипякевич П., Структурные типы интерметаллических соединений, Москва 1977.

Крипякевич П., Фрагменти спогадів (1934-1939), w: Іван Крип'якевич у родинній традиціі, науці, суспільстві, red. Я. Ісаєвич, Ф. Стеблій, Львів 2001.

Петро-Богдан Іванович Крип'якевич (1923-1980). Бібліографічний довідник, red. О. Бодак, Є. Гладишевський, Львів 2003.

Семенишин Д., Пам'яті П. І. Крип'якевича, w: Петро-Богдан Іванович Крип'якевич (1923-1980). Бібліографбічний довідник, red. О. Бодак, Є. Гладишевський, Львів 2003. Франкевич Д., Мій керівник дипломної та дисертаційної робіт, w: Петро-Богдан Іванович Крип'якевич (1923-1980). Бібліографічний довідник, red. О. Бодак, $€$. Гладишевський, Львів 2003. 